DOI: $10.2478 / \mathrm{v} 10025-007-0003-9$

JOURNAL OF WATER

AND LAND DEVELOPMENT

J. Water Land Dev. No. 10, 2006: 39-44

\title{
Implementation of the Water Framework Directive: achievements and lessons learned at the half-way mark
}

\section{Thomas IETSWAART}

Province of Fryslân, the Netherlands

\begin{abstract}
The Netherlands has a long tradition in water management, mainly stemming from the geography of the country. The 'struggle with water' has been organised from medieval times by the water boards (waterschappen), which are the oldest democratic institutions in the Netherlands. Nowadays the water boards, 27 in the whole of the Netherlands, are not only responsible for flood protection and regulation of water levels, but for water quality management and waste water treatment as well. In the years in which the WFD implementation has been underway in the Netherlands, several issues have arisen. Cooperation between all levels of government is key. This requires as clear as possible divisions of competences between the various parties involved. It also takes much time, especially in a process in which many matters have to be invented 'on the fly', such as criteria for designating water bodies, ecological standards, and the formulation of MEP and GEP.
\end{abstract}

Key words: water management, flood protection, water quality, surface water

\section{INTRODUCTION}

The Water Framework Directive entered into force on December 22th, 2000. All EU member states have to implement the directive, leading to River basin management plans (RBMP) in 2009, and (ideally) good status of all European waters in 2015. This is a formidable task, not only to take all necessary measures, but also in an organisational sense. In this paper, the implementation of the WFD in the Netherlands will be described in brief terms. The focus will be on the implementation process. The water quality problems in the Netherlands will be addressed briefly. As a conclusion, some lessons learned during the past years will be mentioned.

\section{DUTCH WATER MANAGEMENT}

The Netherlands has a long tradition in water management, mainly stemming from the geography of the country. The "struggle with water" has been organised 
from medieval times by the water boards (waterschappen), which are the oldest democratic institutions in the Netherlands. Nowadays the water boards, 27 in the whole of the Netherlands, are not only responsible for flood protection and regulation of water levels, but for water quality management and waste water treatment as well.

Water boards are not the only institutions concerned with water management, all levels of government have a role. The central and regional governments are responsible for the strategic planning and setting of water quality targets on the national and regional scale. Water boards translate these strategic plans into measures to be taken to improve water quality. They are also the competent authorities for issuing permits to companies to discharge chemicals into surface waters. Municipalities are responsible for the sewage system, but not for waste water treatment.

The large surface waters, like the large rivers, lakes and the sea, are managed by the national water board, Rijkswaterstaat, which is part of the Ministry of Transport and Water Management.

All this implies that there are many actors concerned with the implementation of the WFD.

\section{WATER QUALITY PROBLEMS}

Holland is very densely populated, industrialised and intensely farmed. It lies in the delta of four international rivers, with many millions of inhabitants. Most water courses have been heavily modified to suit the needs of farmers or to prevent flooding. In the parts below sea level, water levels are tightly regulated, most natural variation has disappeared. This means that the pressures on waters are very high. This has lead to a moderate or to poor water quality, both ecologically and chemically. There are three main pressures:

- emissions of nitrogen and phosphorus from waste water treatment plants and agriculture

- diffuse pollution with heavy metals and other pollutants

- the regulation and modification of water courses

The mentioned pressures have led to lakes and rivers which are turbid, with little or no higher plants, and a fish population with mainly whitefish, such as bream.

The water quality is improving, due to large investments in waste water treatment of both industries and municipalities, and the restoration of rivers and streams. Most point sources have been reduced. For instance almost all municipal waste water treatment plants remove $75 \%$ of nitrogen and phosphorus, required by the Europenan Urban waste water Directive. About $98 \%$ of all households have been 
connected to the sewage system. Despite these efforts, the water quality needs improvement.

Part of the load of chemicals is coming from neighbouring countries, via the large rivers Rhine, Meuse, Scheldt and Ems.

\section{IMPLEMENTATION OF THE WFD IN THE NETHERLANDS}

As described earliers, water management is well developed. The system of plans to lay down strategies, standards and measures is in place. For this reason, the Dutch government decided not to introduce the RBMP as a new plan in the policy making process, but to compile the RBMP from parts of existing plans of the various levels of government. This does however not imply that the implementation of the WFD is easy. Many adjustments to the plans are necessary. There were for instance no standards for ecological quality elements like water plants and fish. All waters had to be assigned to water bodies. A new system of water types was developed. And most importantly, an institutional framework was put in place for the implementation of the WFD. Especially because water management is so fragmented in Dutch policy, there is a need for intensive cooperation between the various authorities. To achieve this, the country is divided into seven sub-basins. The implementation for each sub-basin is coordinated by a regional body of governors, in which governors of provinces, water boards, and municipalities have a seat, as well as representatives of the various ministries. The preparation of documents and other implementation activities is done by working groups answering to the regional board of governors. On a national level, the activities in the seven subbasins are in turn coordinated by a national coordinating officer, who answers directly to the responsible minister.

The implementation process started with the development of several necessary tools, like a water typology, yardsticks for ecological quality elements, a method to derive Maximum and Good Ecological Potential for heavily modified waters and other matters. In 2004, characterisation reports describing water bodies and their ecological and chemical status, pressures and an economical analysis were finalised for all sub-basins and submitted to the European Commission.

The preliminary analysis shows that almost all Dutch water bodies are either heavily modified or artificial. For all these waters, a thorough analysis of the hydromorphological changes has to be made, to determine their effect on the maximum attainable ecological state, in WFD term known as Maximum Ecological Potential (MEP). From the MEP, the actual target for 2015, the GEP is derived. This analysis is now concluded preliminarily for most Dutch waters.

The Guidance paper on heavily modified waters describes a method for the determination of MEP and GEP which starts with the reference condition of the most similar water type. This reference is then corrected for the effects of those 
hydromorphological alterations that are not reversible, because of significant damage to water uses and other human activities. This approach, with a 'natural' starting point has proven to be difficult to implement, and also difficult to explain to politicians and other decision makers. Therefore, on an international workshop in Prague, a new approach was suggested. This approach starts with the current ecological status of a water body. GEP is determined by adding up the ecological improvements of all conceivable measures, both hydromorphological and emissionbased. This method has been used successfully in the Netherlands. The various steps of the method are illustrated in Figure 1.

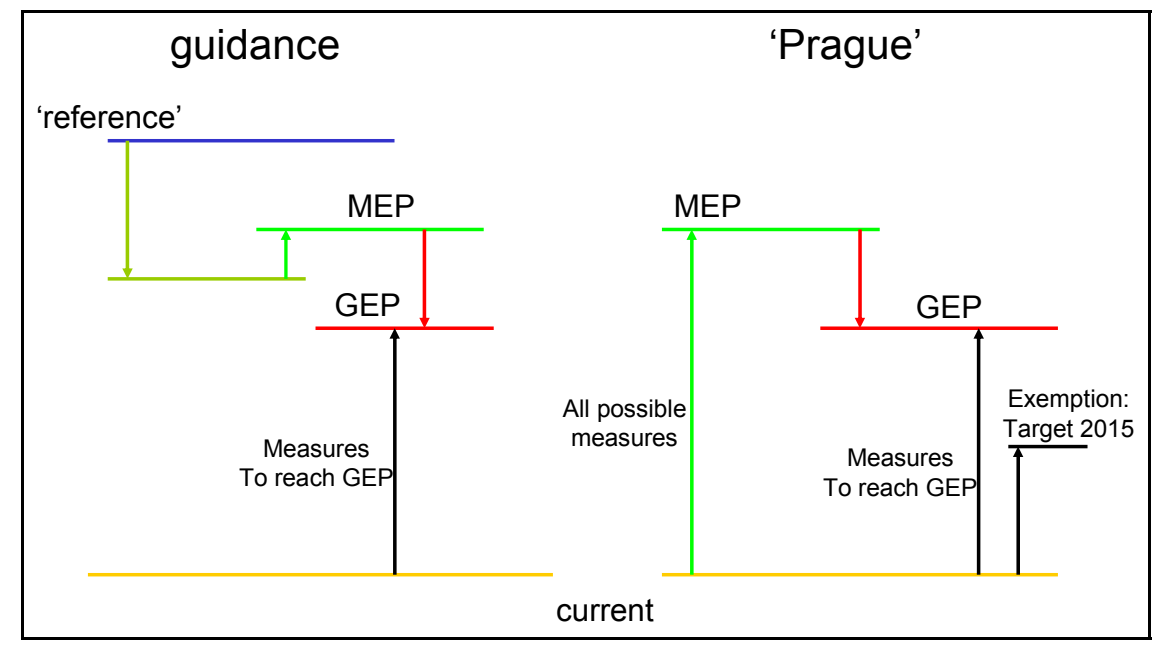

Fig. 1. The scheme of methods for determination of MEP and GEP

\section{POLICY GOALS FOR 2015}

The preliminary assessment of the measures necessary to reach GEP indicate that a large increase in spending on water management is needed. Large sums are required for the restoration of channelised rivers and degraded lake shores, and for additional reduction of emissions from agriculture and point sources. For many regions, the total cost of the measures will be too large to realise in the six-year period (2009-2015) of the first RBMP. Discussions are underway to determine what the maximum effort is which can be achieved with the first RBMP. If this effort is not enough to reach GEP, the WFD provides the instrument of exemption, enabling member states to set interim targets for 2015, and achieve GEP in one of the following RBMP periods. It is conceivable that some goals will prove to be out of reach, even after taking all measures which cause no disproportionate damage to 
the economy or society. In that case, the WFD offers the possibility to set lower environmental targets. If necessary, this decision will most likely be made in 2027.

\section{ROLE OF STAKEHOLDER GROUPS}

Many people are involved in water management. Not only government, but also farmers, water companies, water sports, environmental groups and others have a stake, either as a user of "water services", or as an interest group, protecting economic or ecological values. It is vital that these groups participate in the decision making process of the WFD, to ensure that the policies and measures in the RBMP are broadly supported by all parties involved. Public participation is required by the WFD.

For this reason, local stakeholder groups have been assigned a central role in the formulation of measures to reach the WFD goals. In the groups, representatives of provinces, water boards, municipalities, farmer's unions, environmental groups and others discuss the measures to be taken. The result is ideally consensus about a package of measures and their financing. However, the groups have no power of decision. The packages will therefore be presented to the responsible councils of provinces, municipalities and water boards, which will ultimately decide which measures, will be taken.

At the moment, the process of the stakeholder groups in under way. It should lead to packages of measures in the course of 2007.

\section{LESSONS LEARNED}

In the years in which the WFD implementation has been underway in the Netherlands, several issues have arisen. Cooperation between all levels of government is the key factors. This requires as clear as possible divisions of competences between the various parties involved. It also takes much time, especially in a process in which many matters have to be invented "on the fly", such as criteria for designating water bodies, ecological standards, and the formulation of MEP and GEP.

In relation to this point, it is important to define WFD-terms like "significant damage" or "disproportionate costs" as clearly as possible. The WFD leaves a lot of room for interpretation. The progress of the WFD-process benefits greatly from clear definition of those terms.

With a complex policy process like the implementation of the WFD, things almost never go right the first time. It is important to start with pilot projects as soon as possible, and apply the improved procedures derived from those projects. This holds for each stage in the implementation process. 
Discussion with stakeholders is best organised around concrete measures proposed in clearly defined waterbodies. Stakeholders can relate much better to measures to be taken than to rather vague ecological targets or standards. During this public participation, it is very important to clarify the issues the stakeholders can or cannot influence. With expectations of stakeholders matching actual influence, the participation will remain constructive.

\section{STRESZCZENIE}

\section{Wdrożenie Ramowej Dyrektywy Wodnej: osiągnięcia i doświadczenia zdobyte $w$ połowie drogi}

Stowa kluczowe: gospodarka wodna, jakość wody, ochrona przed powodzia, wody powierzchniowe

Zdobyto wiele doświadczeń w dotychczasowych pracach związanych z wdrożeniem Ramowej Dyrektywy Wodnej. Podstawowym elementem niezbędnym dla osiagnięcia celu RDW jest ścisła współpraca pomiędzy wszystkimi organami rządowymi i administracyjnymi, ponieważ problematyka wodna jest bardzo rozproszona. Stąd też istotnym wymogiem jest wyraźne sprecyzowanie kompetencji poszczególnych organów. Kolejny problem to ustalenie rzeczywistych możliwych do osiagnięcia ekologicznych standardów dla wód powierzchniowych i podziemnych. Okazało się np. że nie jest możliwe osiągnięcie maksymalnego potencjału ekologicznego (MEP) i należało sformułować aktualny potencjał ekologiczny (GEP). Niektóre cele wydaje się, że trzeba będzie przesunać z terminu osiągnięcia 2015 na rok 2027.

Reviewers:

Prof. Waldemar Mioduszewski

Prof. Czestaw Przybyta 